\title{
OPTIMASI DATA LATIH MENGGUNAKAN ALGORITMA GENETIKA UNTUK PERAMALAN HARGA EMAS BERBASIS GENERALIZED REGRESSION NEURAL NETWORK
}

\author{
Gita Indah Marthasari ${ }^{1)}$, Arif Djunaidy ${ }^{2)}$ \\ ${ }^{1}$ Jurusan Teknik Informatika, Fakultas Teknik, Universitas Muhammadiyah Malang \\ Jl. Raya Tlogomas No. 246 Malang 65144, Jawa Timur \\ Telp: (0341) 4641819, Fax: (0341) 460782 \\ ${ }^{2}$ Jurusan Sistem Informasi, Fakultas Teknologi Informasi, Institut Teknologi Sepuluh Nopember \\ Kampus Keputih, Sukolilo, Surabaya 60111 \\ Telp: (031) 5999944, Fax: (031) 5964965 \\ E-mail: gita.voyager@gmail.com
}

\begin{abstract}
The prediction of gold price is an important activity for all parties. One of the gold prediction methods that can be used is the artificial neural network based on the generalized regression neural network (GRNN). In the previous research, GRNN was combined with the decomposition technique of Seasonal Trend Decomposition based on locally weighted regression (STL) and the Theta method. The GRNN performance was influenced by the training data used due to the network size formed which is in line proportionally with the training data. To cope the increasing of the network size along with the increasing the training data, we need to do the process of the reduction training data without decreasing the accuracy of the prediction. In this research, the GRNN prediction method is integrated with the genetic algorithm to reduce the training data to produce the more efficient prediction model. Before predicted, the gold price data is decomposed by using STL to become the component of seasonal data, trends, and residual. Those three components are predicted by using two different methods, namely GRNN to predict the component of the seasonal data and residual, and the theta method to predict the trend data component. The prediction result of those three components are combined by using the back propagations neural network algorithm to get the final result of the prediction. The testing result shows that GRNN integrated with the genetic algorithm, is not only able to produce the prediction with the accuracy similar to GRNN without the genetic algorithm, but also able to give the better accuracy comparing to the prediction result by using the Arima prediction model. Beside that, the combination of GRNN with the genetic algorithm is able to reduce the amount of the training data as much as $50 \%$ and able to reduce the time of the prediction process as much as $34 \%$.
\end{abstract}

\section{Abstrak}

Peramalan harga emas di masa mendatang merupakan sebuah hal penting bagi banyak pihak. Generalized regression neural network (GRNN) merupakan salah satu jenis jaringan syaraf tiruan yang dapat digunakan untuk memprediksi harga emas. Dalam penelitian sebelumnya, GRNN digabungkan dengan teknik dekomposisi berbasis Seasonal Trend Decomposition based on Loess (STL) dan metode theta. STL digunakan untuk mendekomposisi data runut waktu menjadi komponen data musiman, tren, dan residual. Selanjutnya, setiap komponen data diramalkan menggunakan dua metode yang berbeda, yaitu GRNN untuk meramalkan komponen data musiman dan residual, sedang metode theta untuk meramalkan komponen data tren. Hasil peramalan dari ketiga komponen data tersebut selanjutnya digabungkan menggunakan jaringan syaraf tiruan propagasi balik untuk mendapatkan hasil peramalan akhir. Kinerja GRNN dipengaruhi oleh data latih yang digunakan karena ukuran jaringan yang terbentuk berbanding lurus dengan jumlah data latih. Untuk mengatasi meningkatnya ukuran jaringan seiring dengan bertambahnya data latih, proses reduksi data latih perlu dilakukan. Dalam penelitian ini, arsitektur GRNN dibangun dengan data latih yang sebelumnya direduksi dengan menggunakan algoritma genetika. Hasil pengujian menunjukkan bahwa GRNN yang dikombinasikan dengan algoritma genetika selain mampu menghasilkan peramalan dengan akurasi yang setara dengan GRNN tanpa algoritma genetika juga mampu memberikan akurasi yang lebih baik dibandingkan dengan hasil permalan menggunakan model peramalan Arima. Selain itu, kombinasi GRNN dengan algoritma genetika mampu mereduksi jumlah data latih sebesar 50\% dan mampu mengurangi waktu proses peramalan sebesar $34 \%$.

Kata kunci: prediksi harga emas, optimasi data latih, algoritma genetika, dekomposisi data runut waktu, generalized regression neural network, metode theta. 


\section{PENDAHULUAN}

Emas merupakan sebuah aset dasar dari investasi atau portofolio. Emas telah terbukti sebagai simpanan tunai yang efektif selama krisis saham pada tahun 1987, dan krisis moneter Asia pada tahun 1997 dan 1998. Selama beberapa tahun terakhir, makin banyak investor yang tertarik berinvestasi pada komoditas ini. Fenomena ini antara lain disebabkan oleh adanya ketidakstabilan nilai mata uang resmi dan kecenderungan nilai emas yang meningkat (Assimakopoulos, 2000) . Para investor tertarik untuk berinvestasi pada komoditas yang nilainya relatif aman dan stabil. Harga emas dari tahun ke tahun menunjukkan tren peningkatan. Hal ini dapat diamati dari grafik harga emas dimana terdapat kecenderungan peningkatan harga dari tahun ke tahun. Selain itu, harga emas juga memiliki komponen data musiman (seasonality) yaitu periode waktu dimana harga emas cenderung tinggi. Menurut Linde (2001), periode kenaikan harga emas terjadi pada kuartal keempat setiap tahunnya yaitu mulai bulan September hingga Desember. Menurutnya, hal ini didorong oleh peningkatan permintaan akan emas oleh masyarakat di India yang turut mempengaruhi naiknya harga emas. Pengetahuan terhadap harga emas di masa mendatang merupakan sebuah hal penting bagi banyak pihak. Witjaksono (2010) melakukan penelitian untuk mengetahui faktor-faktor yang mempengaruhi indeks harga saham gabungan (IHSG) di Bursa Efek Indonesia. Salah satu variabel yang diteliti adalah harga emas. Berdasarkan pengujian, variabel harga emas merupakan faktor dominan dalam perubahan IHSG. Wang, dkk (2012) yang meneliti mengenai hubungan antara harga emas dan harga minyak mentah menemukan bahwa keduanya saling mempengaruhi. Hussein dkk (2011) dan Sopipan, dkk (2012) menunjukkan potensi emas sebagai bentuk investasi yang menguntungkan. Shafiee, dkk (2010) menyatakan bahwa prediksi harga emas penting bagi perusahaan pertambangan sebagai acuan dalam pengambilan keputusan kelayakan sebuah proyek.

Selain metode pemodelan tradisional, para peneliti telah banyak menggunakan jaringan syaraf tiruan (JST) dalam peramalan. Sebagai contoh, Hussein, dkk. (2011) yang membandingkan antara radial basis function neural network (RBFNN) dengan metode model autoregressive, Parisi, dkk. (2011) yang menggunakan jaringan syaraf rolling dan recursive, Zou dkk. (2007) dan Hansen, dkk. (2003) yang membandingkan antara JST dengan ARIMA, Theodosiou (2011) yang mengombinasikan model JST generalized regression (GRNN) dan metode theta, dan $\mathrm{Ka}-$ astra, dkk. (1996) yang menggunakan JST untuk melakukan peramalan di bidang ekonomi dan keuangan. Beberapa peneliti tersebut memperoleh kesimpulan berbeda berkaitan dengan hasil peramalan menggunakan JST. Masing-masing pendekatan baik tradisional maupun JST memiliki keunggulan dan kelemahan.

Penelitian di bidang peramalan harga emas dengan menggunakan JST bukanlah topik baru. McCann, dkk (1994) menggunakan jaringan syaraf rekursif untuk mengenali titik-titik perubahan pada pasar emas berdasarkan sepuluh indikasi dari data-data historis yang hasilnya membawa keuntungan pada periode tertentu. Parisi, dkk. (2008) menggunakan jaringan syaraf rekursif dan berputar untuk meramalkan harga emas. Hasil dari penelitian ini disimpulkan bahwa pendekatan ini dapat mengurangi resiko pada transaksi emas dan dapat menjadi alternatif pengganti pemodelan ARIMA. Hussein dkk. (2011) melakukan peramalan harga emas menggunakan radial basis function neural network (RBFNN) yang kemudian dibandingkan akurasinya dengan pemodelan autoregressive. Tipe RBFNN yang digunakan adalah tunggal dan jamak dimana berdasarkan pengujian tingkat akurasi RBFNN jamak lebih tinggi dibandingkan RBFNN tunggal namun akurasi hasil dari kedua tipe RBFNN ini masih kalah dibandingkan ARIMA. Menurut Theodosiu (2011), akurasi peramalan dengan jaringan syaraf dapat ditingkatkan dengan terlebih dahulu mendekomposisi data runut waktu. Data yang digunakan dalam peramalan dengan JST minimal dibagi menjadi dua kelompok yaitu data latih untuk membentuk model dan data uji untuk menguji model. Salah satu model JST yang banyak digunakan dalam peramalan adalah generalized regression neural network (GRNN). Dalam penelitiannya, Theodosiou menggunakan GRNN untuk peramalan runut waktu yang dikombinasikan dengan metode theta. Sebelum diramalkan, data runut waktu didekomposisi terlebih dahulu menggunakan metode STL (Seaso-nal Trend Decomposition based on Loess) untuk memisahkan komponen data kecenderungan (trend) dan komponen musiman. Metode GRNN digunakan untuk meramalkan komponen data musiman dan residual, sedangkan peramalan komponen data tren dilakukan dengan metode Theta. Salah satu karakteristik GRNN adalah ukuran jaringan akan bertambah seiring meningkatnya jumlah data latih. Specht [14]. Oleh karena itu, pada penelitian ini GRNN akan diintegrasikan dengan algoritma genetika untuk seleksi data latih sehingga menghasilkan struktur jaringan yang lebih efisien dan peramalan harga emas yang lebih akurat. 
Marthasari, dkk., Optimasi Data Latih menggunakan Algoritma Genetika untuk Peramalan..

\section{METODOLOGI}

Tujuan dari penelitian ini adalah mengimplementasikan metode generalized regression neural network (GRNN) dan metode theta untuk menghasilkan peramalan harga emas yang lebih akurat. GRNN akan dikombinasikan dengan algoritma genetika untuk seleksi data latih dengan tujuan meningkatkan akurasi peramalan oleh GRNN. GRNN merupakan bentuk modifikasi dari radial basis function neural network (RBFNN) (Kim, 2008). GRNN adalah sebuah jaringan syaraf yang didasarkan pada teori regresi nonlinier. Menurut Theodosiou (2011), penggunaan GRNN dapat mengurangi kesulitan dalam merancang dan menguji-coba jaringan syaraf akibat adanya parameter bebas. Jenis jaringan ini, yang dikembangkan oleh Specht 1991), menunjukkan kelebihan penting dibandingkan arsitektur jaringan syaraf standar seperti jaringan syaraf runut maju propagasi balik (RMPB). Topologi GRNN terdiri atas empat lapisan, yaitu lapisan masukan, lapisan basis radial atau lapisan pola (pattern) atau lapisan tersembunyi (hidden), lapisan penggabungan (summation), dan lapisan keluaran (Duzgun, 2010). Lapisan pertama, lapisan tersembunyi dan lapisan penggabungan memiliki koneksi penuh, sedangkan lapisan keluaran hanya terhubung ke beberapa neuron pada lapisan penggabungan. Lapisan penggabungan terdiri atas dua tipe neuron yaitu satu atau lebih simpul penggabungan (summation) dan sebuah simpul pembagian (division). Banyaknya neuron penggabungan disesuaikan dengan banyaknya neuron pada layer keluaran (Kim, 2008). Simpul pembagian tidak menggunakan fungsi transfer, tetapi menggunakan fungsi penjumlahan nilai keluaran terbobot dari lapisan pola. Setiap simpul pada lapisan keluaran terkoneksi ke simpul penggabungan dan pembagian di lapisan penggabungan, dan tidak ada bobot pada koneksi antara lapisan penggabungan dan lapisan keluaran. Nilai keluaran dari lapisan keluaran dihitung dengan membagi perhitungan nilai keluaran dari simpul penggabungan dengan perhitungan nilai keluaran dari simpul pembagian pada lapisan penggabungan. Gambar 1 menunjukkan arsitektur dari GRNN. Dalam GRNN terdapat sebuah parameter bebas yaitu parameter penghalusan (smoothing parameter) atau penyebaran $($ spread) atau sigma $(\sigma)$. Nilai sigma akan menentukan derajat generalisasi dari GRNN. Semakin tinggi nilai sigma maka akan meningkatkan kemampuan jaringan dalam memprediksi dan mengurangi kesalahan prediksi, sedangkan nilai sigma yang terlalu rendah akan menghilangkan kemampuan jaringan dalam memprediksi sehingga perlu dicari nilai sigma yang optimal.

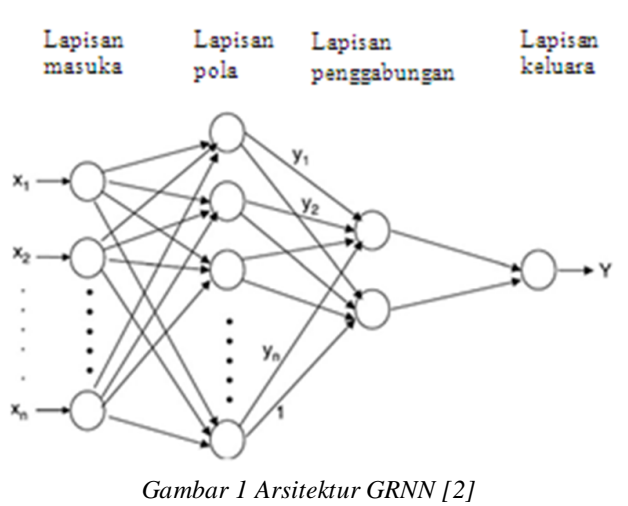

Dalam penelitian ini, GRNN akan dikombinasikan dengan STL dan GA. Adapun rancangan model penelitian ditunjukkan pada Gambar 2. Kedua tahap pada Gambar 2 dapat dijelaskan pada sebagai berikut :

a. Tahap1

Data harga emas harian dalam bentuk data runut waktu $(x(t))$ didekomposisi menggunakan metode STL [3]. Hasil dekomposisi adalah komponen data siklus-tren (trend-cycle) $T(t)$, komponen musiman (seasonal) $S(t)$, dan komponen residual (irregular) $I(t)$. Dengan demikian, untuk setiap runut waktu $x_{t}$, STL akan menghasilkan: $m_{t}, s_{t}$, dan $e_{t}$ yang secara berturut-turut adalah komponen data tren, komponen musiman, dan komponen residual dari data runut waktu sesuai dengan persamaan 1 .

$$
x_{t}=m_{t}+s_{t}+e_{t}
$$

\section{b. Tahap2}

Langkah kedua adalah meramalkan ketiga komponen hasil dekomposisi. Komponen data musiman $(S(t))$ dan residual $(I(t))$ diprediksi menggunakan GRNN yang dikombinasikan dengan algoritma genetika (GA), sedangkan komponen data tren $(T(t))$ diprediksi dengan model theta karena GRNN kurang sesuai untuk meramalkan komponen data tren (Theodosiou, 2011). Hasil peramalan ketiga komponen digabungkan dengan algoritma JST propagasi balik untuk memperoleh nilai ramalan

Algoritma genetika merupakan teknik pencarian nilai optimum secara stokastik berdasarkan prinsip dasar dari teori evolusi. Algoritma genetika melakukan proses pencarian nilai optimum pada beberapa titik secara bersamaan (satu generasi) Kosasih. Proses iterasi kemudian dilakukan dengan pendekatan generasi ke generasi yang mengalami proses evolusi, tetapi jumlah anggota/ kromosom pada setiap generasi, yang merupakan kumpulan solusi, umumnya dipertahankan tetap. 


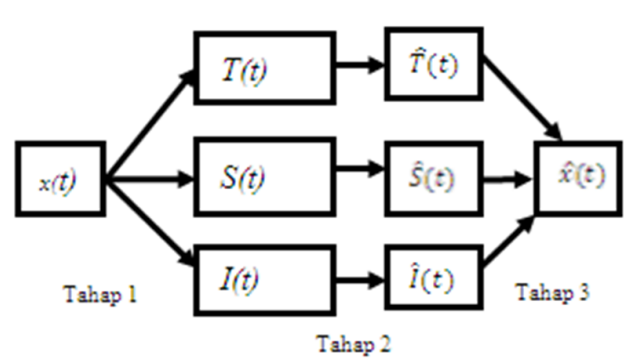

Gambar 2 Model peramalan harga emas STL-GRNN-GATheta

Kromosom yang dianalisis dapat merupakan kode biner, integer atau desimal. Dalam proses evolusi, sejumlah gen yang membentuk kromosom melewati proses crossover (kawin silang) dan/atau mutasi (perubahan gen secara alami). Kromosom yang baik akan terus hidup, sedangkan kromosom yang buruk akan mati dengan sendirinya. Algoritma genetika menggunakan hukum transisi probabilistik untuk memilih solusi (kromosom) yang terus dipertahankan hidup sesuai dengan ketentuan yang diinginkan (fitness function), sehingga proses pencarian solusi optimum dapat diarahkan ke arah yang diperkirakan akan lebih baik. Algoritma genetika akan digunakan untuk memilih vektor latih dari keseluruhan vektor latih yang ada.

Model theta merupakan sebuah metode dekomposisi yang dapat mendekomposisi komponen data musiman dari sebuah data runut waktu dan menghasilkan komponen jangka pendek dan jangka panjang (Assimakopoulos, 2000). Model ini didasarkan pada konsep untuk memodifikasi lengkungan lokal dari data runut waktu. Modifikasi ini ditentukan oleh sebuah koefisien, yang disebut dengan koefisien Theta $(\theta)$ dan diterapkan pada perbedaan kedua dari data seperti pada persamaan 2 dimana = $X_{t}-2 X_{t-1}+X_{t-2}$ pada waktu $t$. Pada penelitian ini, digunakan fungsi thetaf() pada paket forecast di perangkat lunak $\mathrm{R}$.

$$
x_{\text {new }}(\theta)=\theta \cdot x_{\text {data }}
$$

Tahap-tahap peramalan menggunakan GRNNGA adalah penyiapan data latih, pengkodean kromosom, evaluasi populasi, seleksi, rekombinasi, dan mutasi. Penjelasan setiap tahap adalah sebagai berikut:

\section{a. Penyiapan data latih}

Untuk keperluan pelatihan dan validasi data, digunakan data mulai tanggal 1 Januari 2003 sampai dengan 31 Desember 2013 dengan total sebesar 2.869 data. Proses pelatihan GRNN-GA menggunakan sebanyak 2.609 data sedangkan validasi menggunakan 260 data. Selanjutnya, untuk dapat diproses menggunakan GRNN-GA data runut waktu harus ditransformasikan menjadi matriks yang berisi data masukan dan target/keluaran. Untuk menggambarkan proses transformasi ini, misalnya akan diramalkan nilai entitas esok hari berdasarkan nilai hari ini dan kemarin, maka nilai entitas esok hari menjadi variabel target sedangkan nilai hari ini dan kemarin menjadi variabel masukan. Prosedur ini dilakukan secara berulang dengan menggeser jendela masukan dan target sesuai dengan banyaknya data runut waktu. Berdasarkan prosedur ini, disusun matriks masukan dan target dari data runut waktu. Untuk 100 data observasi dan dua variabel masukan, jika nilai $(t)$, nilai $(t+1)$ dan nilai $(t+2)$ berturut-turut adalah nilai entitas kemarin, hari ini, dan esok hari dengan $t=1,2,3,4,5, \ldots, 98,99,100$, maka prosedur pembentukan matriks ditunjukkan pada Gambar 3. Pembentukan matriks data validasi juga mengikuti prosedur yang sama.

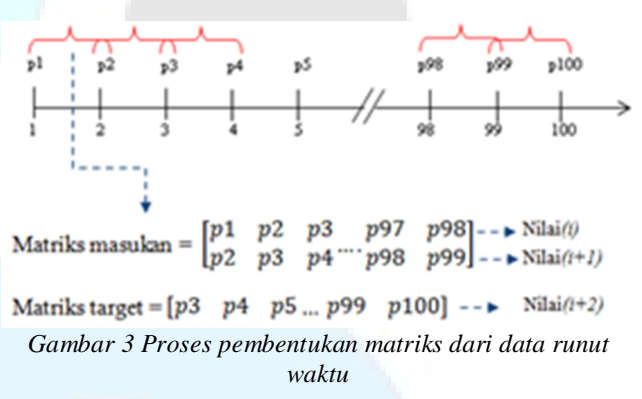

b. Pengkodean kromosom

Data dalam bentuk runut waktu diubah terlebih dahulu menjadi bentuk pasangan masukan dan keluaran sesuai pada tahap sebelumnya. Jumlah data masukan akan menunjukkan banyaknya simpul masukan pada GRNN, sedangkan banyaknya data keluaran menunjukkan banyaknya simpul keluaran GRNN. Banyaknya simpul masukan GRNN menunjukkan $n$ hari sebelum hari prediksi, sedangkan banyaknya simpul keluaran menunjukkan $m$ hari yang akan diprediksi. Matriks latih yang terbentuk selanjutnya akan dibagi menjadi data latih dan data uji dengan perbandingan 70:30. Pada penelitian ini, nilai $n$ dicari melalui uji coba, sedangkan nilai $m$ ditetapkan satu. Untuk jumlah data latih sebanyak $l$, maka matriks data masukan akan berukuran $l x$ $n$, sedangkan matriks data keluaran berukuran $l$ $x m$. Nilai $l$ dipengaruhi oleh ukuran simpul masukan $n$. Format kromosom menggunakan pengodeaan biner dengan panjang kromosom sebanyak data latih awal $(l)$. Nilai satu atau nol menunjukkan masuk atau tidaknya baris pada matriks latih awal ke dalam matriks latih seleksi. Populasi yang terdiri atas sejumlah kromosom yang dibangkitkan secara acak. 
Marthasari, dkk., Optimasi Data Latih menggunakan Algoritma Genetika untuk Peramalan..

c. Evaluasi populasi

Tiap kromosom pada populasi selanjutnya akan dievaluasi untuk ditentukan nilai fitness-nya. Fungsi obyektif yang digunakan adalah fungsi perhitungan root mean squared error (RMSE). Pada proses evaluasi, dihitung RMSE peramalan menggunakan GRNN berbasis matriks latih seleksi dan berbasis matriks latih keseluruhan. RMSE diperoleh dari hasil pengujian outsample yaitu pengujian dengan menggunakan $30 \%$ data yang berbeda dari data latih. Adapun fungsi fitness untuk individu $f(i)$ yang digunakan adalah pembagian antara RMSE GRNN menggunakan matriks latih keseluruhan dan RMSE GRNN menggunakan matriks latih seleksi yang ditunjukkan pada persamaan 3 .

$$
f(i)=\frac{R M S E_{(G R N N)}}{R M S E_{(G R N N-G A)}}
$$

d. Seleksi, rekombinasi, dan mutasi

Seleksi merupakan mekanisme untuk membentuk populasi yang mempertahakan individu dengan fitness tinggi dan mengeliminasi individu dengan fitness yang lebih rendah. Mekanisme rekombinasi yang digunakan adalah memilih dua individu secara acak dari populasi kemudian mengubah bit pada posisi yang sama dari kedua individu tersebut. Adapun proses mutasi dilakukan dengan secara acak memilih salah satu bit pada kromosom kemudian membaliknya yaitu mengubah nol menjadi satu atau mengubah satu menjadi nol.

\section{c. Tahap 3}

Hasil peramalan dari setiap komponen, baik komponen data musiman, tren, dan residual, disintesis menggunakan algoritma jaringan syaraf tiruan propagasi balik untuk mendapatkan peramalan tunggal.

\section{HASIL DAN PEMBAHASAN}

Dalam penelitian ini, data uji coba diperoleh dari situs World Gold Council (http://www.gold.org/). Data tersebut berupa harga emas harian selama 10 tahun mulai tanggal 1 Januari 2003 hingga 31 Desember 2012 dengan total jumlah data adalah 2609 data tidak termasuk hari libur. Nominal yang digunakan adalah dollar (USD) yang menunjukkan harga emas per troy ounce. Dari seluruh data yang ada, data 3 tahun terakhir atau sebanyak 30\% dari keseluruhan data digunakan sebagai data uji dan data 7 tahun pertama atau $70 \%$ digunakan sebagai data latih awal.

\subsection{Dekomposisi}

Sebelum dimodelkan menggunakan GRNN, data harga emas harian didekomposisi terlebih dahulu menggunakan metode STL. Parameter yang ditentukan pada metode STL adalah jendela musiman, nilai parameter low-pass filter, jumlah iterasi dalam, dan jumlah iterasi luar. Nilai jendela musiman ditentukan berdasarkan rata-rata jumlah hari dalam satu tahun yaitu 261, nilai parameter low-pass filter disamakan dengan frekuensi data runut waktu yaitu 261, jumlah iterasi dalam adalah 0 , dan jumlah iterasi luar adalah 0 . Penentuan parameter ini mengacu pada penelitian oleh Cleveland (1990). Hasil dekomposisi harga emas harian menggunakan STL dapat dilihat pada Gambar 4.

\subsection{Penentuan parameter model GRNN untuk komponen data musiman $(S(t))$ dan komponen residual $(I(t))$}

GRNN akan digunakan untuk memodelkan dua komponen dari hasil dekomposisi yaitu komponen data musiman dan komponen residual. Untuk pemodelan kedua komponen menggunakan GRNN, terdapat beberapa parameter yang harus ditentukan terlebih dahulu baik terkait dengan GRNN maupun algoritma genetika. Parameter ini adalah jumlah simpul masukan jaringan, faktor penyebaran (spread), jumlah individu dalam populasi, nilai probabilitas mutasi, dan jumlah generasi. Penentuan parameter model GRNN untuk kedua komponen ini dilakukan terpisah karena masing-masing komponen memiliki karakteristik data yang berbeda seperti yang terlihat pada gambar 4 .

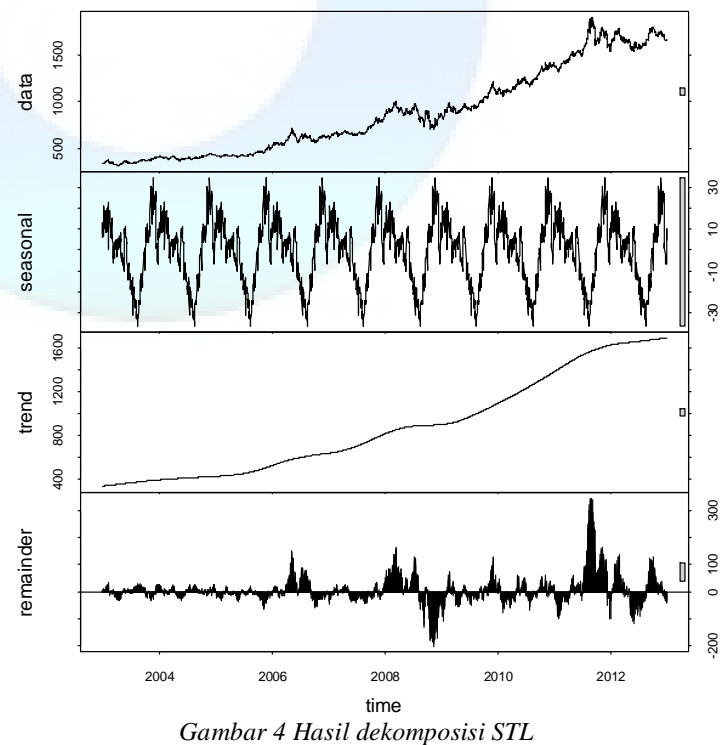

Gambar 4 Hasil dekomposisi STL 
Tabel 1 Hasil uji coba penentuan parameter

\begin{tabular}{|c|c|c|c|}
\hline Parameter & $\begin{array}{l}\text { Komponer } \\
\text { data } \\
\text { musiman }\end{array}$ & & $\begin{array}{l}\text { Komponen } \\
\text { data } \\
\text { residual }\end{array}$ \\
\hline $\begin{array}{l}\text { Simpul masukan } \\
\text { GRNN }\end{array}$ & 75 & 1 & \\
\hline $\begin{array}{l}\text { Nilai spread } \\
\text { GRNN }\end{array}$ & 6 & 20 & \\
\hline $\begin{array}{l}\text { Jumlah populasi } \\
\text { GA }\end{array}$ & 30 & 90 & \\
\hline $\begin{array}{l}\text { Probabilitas } \\
\text { mutasi GA }\end{array}$ & 0.3 & 0.3 & \\
\hline $\begin{array}{l}\text { Jumlah generasi } \\
\text { GA }\end{array}$ & 75 & 90 & \\
\hline
\end{tabular}

Uji coba dilakukan dengan membagi data menjadi data latih dan data uji. Akurasi pengujian model dihitung menggunakan formula root mean square error (RMSE). Untuk tiap parameter yang dicari, diujikan beberapa nilai dan dilakukan sebanyak lima kali uji coba dengan nilai tersebut. Selanjutnya ditentukan nilai RMSE terbaik untuk tiap uji coba. Hasil uji coba penentuan parameter dapat dilihat pada Tabel 1 .

\subsection{Perbandingan beberapa metode peramalan}

Uji coba dilakukan untuk mengukur kinerja metode peramalan yang dikembangkan dalam penelitian ini dibandingkan dengan beberapa metode peramalan lain. Metode lain yang digunakan adalah STL-GRNN-Theta dan metode peramalan ARIMA. Langkah pertama adalah menguji hasil peramalan menggunakan STLGRNN-GA-Theta. Metode GRNN-GA digunakan untuk meramalkan komponen data musiman dan residual, sedangkan komponen data tren diramalkan menggunakan metode theta. Untuk menemukan model GRNN-GA yang terbaik, dilakukan iterasi sebanyak lima kali untuk masing-masing komponen data musiman dan residual Untuk komponen data musiman, parameter GRNN yang diatur adalah jumlah simpul masukan sebanyak 75 yang menunjukkan lebar jendela observasi dan nilai penyebaran sebesar enam. Sedangkan untuk parameter algoritma genetika yang digunakan untuk peramalan komponen data musiman menggunakan GRNN yaitu jumlah populasi 30, probabilitas mutasi 0.4 , dan jumlah generasi 90 . Untuk komponen residual, parameter GRNN yang diatur adalah jumlah simpul masukan sebanyak satu dan nilai penyebaran sebesar 20. Sedangkan untuk algoritma genetika, parameter yang digunakan yaitu jumlah populasi 90 , probabilitas mutasi 0.4 , dan jumlah generasi 90. Peramalan kedua komponen selanjutnya digabungkan dengan hasil peramalan komponen data tren yang menggunakan metode theta. Penggabungan dilakukan menggunakan metode JST propagasi balik.

Langkah kedua adalah melakukan peramalan menggunakan STL-GRNN-Theta. Peramalan diterapkan terhadap komponen data musiman dan residual dengan menggunakan metode GRNN dan komponen data tren menggunakan metode theta. Parameter untuk GRNN untuk komponen residual adalah jumlah simpul masukan sebanyak satu dan nilai parameter penyebaran 20. Untuk komponen data musiman, jumlah simpul masukan adalah 75 dan nilai penyebaran enam. Hasil peramalan komponen data musiman, residual, dan tren digabungkan menggunakan metode JST propagasi balik.

Peramalan menggunakan ARIMA dilakukan dengan menerapkan pemilihan model secara otomatis menggunakan algoritma pemilihan stepwise yang diimplementasikan dalam perangkat lunak R yaitu fungsi auto.arima(). Untuk pemodelan, digunakan $70 \%$ data yaitu sebanyak 1826 observasi untuk meramalkan 783 hari ke depan. Parameter Arima terbaik yang diperoleh adalah $\mathrm{p}=0, \mathrm{~d}=1$, dan $\mathrm{q}=0$. Perbandingan hasil peramalan dapat dilihat pada Gambar 5. Dari gambar tersebut terlihat bahwa peramalan menggunakan metode STL-GRNN-GA-Theta menghasilkan tingkat akurasi yang lebih baik dibandingkan dengan metode STL-GRNNTheta dan ARIMA. Kombinasi dengan GA juga berhasil memperkecil ukuran jaringan sebesar $50 \%$ dari ukuran semula.

Untuk mengetahui validitas model, digunakan perhitungan uji variasi amplitudo atau \% error variance. Model disebut valid jika nilai error variance kurang dari $30 \%$. Berdasarkan perhitungan, model peramalan STL-GRNN-GA-Theta memiliki nilai error variance sebesar 0.0058368 atau $0.5 \%$ sedangkan model STL-GRNN-Theta nilai memberikan error variance sebesar 0.019873 atau $1.9 \%$. Dengan demikian, model peramalan STL-GRNN-GA-Theta adalah valid.

\section{KESIMPULAN dan SARAN}

Penelitian telah berhasil memodifikasi metode peramalan berbasis Seasonal Trend based on LOESS (STL)-Generalized Regression Neural Network (GRNN)-Theta menjadi STL-GRNNTheta berbasis algoritma genetika sehingga menghasilkan peramalan yang akurat dan efisien. Berdasarkan hasil uji variasi amplitudo, model STL-GRNN-GA-Theta dapat dinyatakan valid dengan error variance $0.5 \%$. 


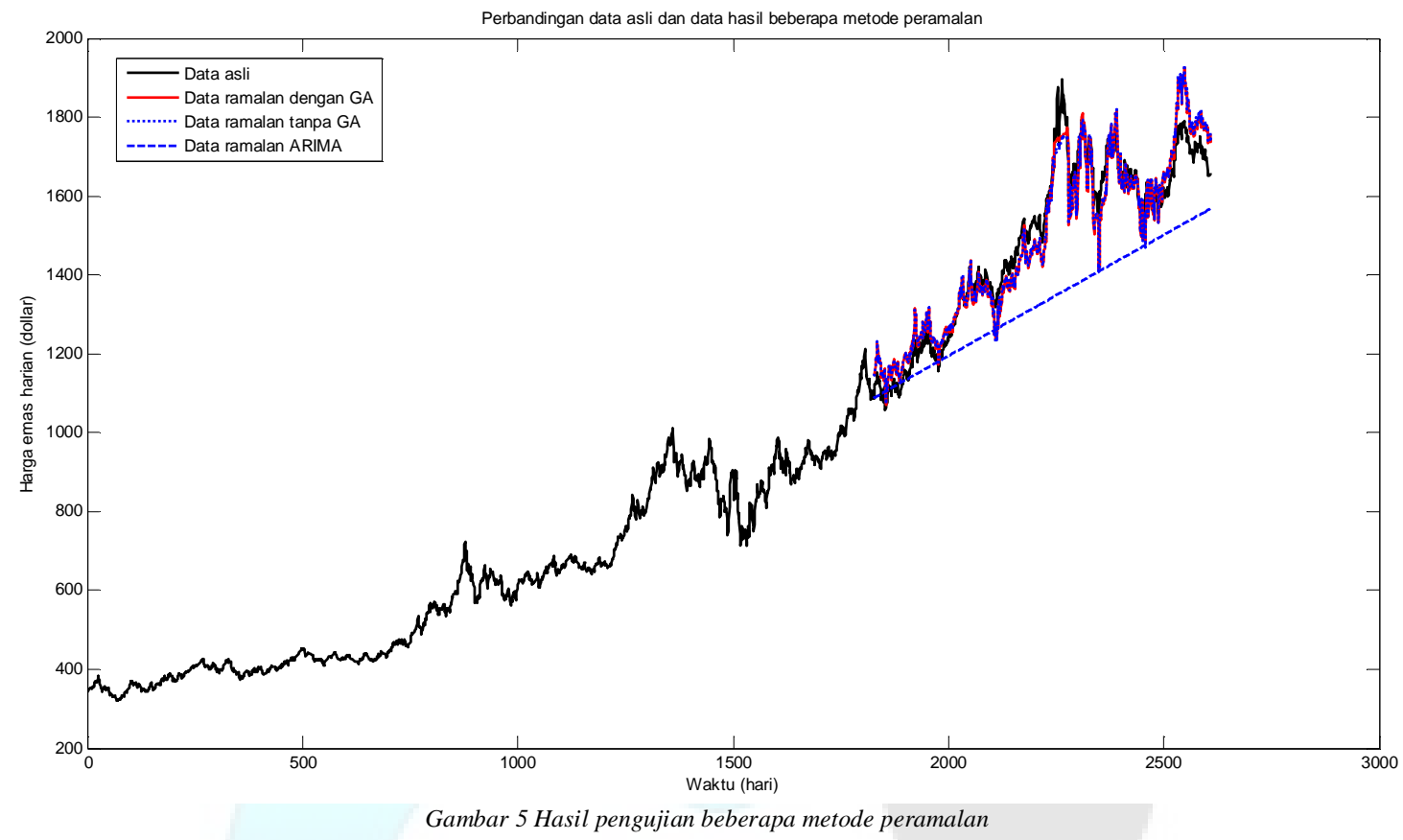

Dari hasil uji coba penentuan parameter model peramalan dapat disimpulkan bahwa hasil terbaik peramalan untuk komponen data musiman diperoleh dengan menggunakan rentang jendela observasi sebesar 75, sedangkan untuk komponen residual diperoleh rentang terbaik untuk jendela observasi adalah satu.

Dari hasil uji coba perbandingan peramalan dengan beberapa metode lainnya dapat disimpulkan bahwa peramalan yang mengintegrasikan STL-GRNN-Theta dan algoritma genetika memberikan hasil yang lebih baik dibandingkan dengan metode STL-GRNN-Theta dan dibandingkan metode peramalan ARIMA. Metode STL-GRNN-Theta-GA memberikan hasil peramalan dengan RMSE sebesar 121.8702 dengan pengurangan data latih sebesar 51,2\% untuk komponen musiman dan 50,1\% untuk komponen data residual. Dengan berkurangnya data latih, waktu pemrosesan menggunakan GRNN berkurang dari 1.4976 detik menjadi 0.5148 atau sebesar $65,6 \%$. Sedangkan jika dibandingkan dengan ARIMA, model STL-GRNNGA-Theta memberikan akurasi 44,1\% lebih baik dibandingkan RMSE peramalan menggunakan ARIMA.

Dalam penelitian ini, GA yang digunakan untuk memilih data latih membutuhkan waktu lama dalam pengaturan nilai parameter dan model harus selalu dilatih setiap tahunnya untuk meramalkan data satu tahun ke depan. Oleh karena itu, perlu diimplementasikan pembelajaran berkelanjutan bagi model sehingga ketika ada penambahan data tidak perlu mengulang keseluruhan proses pelatihan. Selain itu, pera- malan yang dilakukan dalam penelitian ini masih berupa potongan-potongan program yang terpisah satu dengan lainnya, maka adanya sebuah aplikasi dengan antarmuka terintegrasi diperlukan agar peramalan yang dikembangkan dalam penelitian ini dapat digunakan dengan mudah. Program aplikasi tersebut harus menyediakan antarmuka yang akan memudahkan pengguna menerapkan berbagai skenario peramalan.

\section{DAFTAR RUJUKAN}

Assimakopoulos, V. dan Nikolopoulos, K. 2000. The Theta Model : a Decomposition Approach for Forecasting. International Journal of Forecasting 16, pp. $521-530$.

Cigizoglu, H.K. 2005. Generalized Regression Neural Network in Monthly Flow Forecasting. Civil Engineering and Environmental Systems, vol. 22, no. 2, Juni 2005, pp. $71-84$.

Cleveland, R.B., Cleveland, W.S., McRae, J.E., dan Terpenning, I. 1990. STL : a Seasonaltrend Decomposition Procedure Based on Loess. Journal of Official Statistics, vol. 6, no. 1, 1990, 3-73.

Duzgun, R. 2010. Generalized Regression Neural Network for Inflation Forecasting. International Research Journal of Finance and Economics 51, hal. 59 - 70.

Hansen, J.V., Nelson, R.D. 2003. Forecasting and Recombining Time Series Components by using Neural Network. Journal of the Operational Research Society (2003) 54, 307-317. 
Hussein, S.F.M, Shah, M.B.N., Jalal, M.R.A., dan Abdullah, S.S. 2011. Gold Price Prediction using Radial Basis Function Neural Network. Proceeding of International Conference of Modelling, Simulation and Applied Optimization (ICMSAO), Kuala Lumpur, Malaysia, 1921 April 2011, pp. 1-11.

Kaastra, I., Boyd, M. 1996. Designing a Neural Network for Forecasting Financial and Economic Time Series. Neurocomputing vol. 10, $215-236$.

Kim, S. dan Kim, H.S. 2008. Neural Networks and Genetic Algorithm Approach for Nonliniear Evaporation and Evapotranspiration Modeling. Journal of Hydrology, vol. 351, pp. 299-317.

Kosasih, D. dan Rinaldo. Analisis aplikasi algoritma genetika untuk pencarian nilai fungsi maksimum. Makalah tidak diterbitkan.

Linde, Damon van der. 2011. The Seasonal Trends of Gold Prices. Artikel di Gold Investing News (http://goldinvestingnews.com/14894/the-seasonal-trends-of-goldprices.html)

McCann, P., Kalman, B., 1994. A Neural Network Model for the Gold Market. Washington University in St. Louis, Part of the Philosophy Neuroscience and Psychological Technical Report Series.

Parisi, A., Parisi, F., Diaz, D. 2008. Forecasting Gold Price Changes : Rolling and Recursive Neural Network. Journal of Multinational Financial Management 18, $477-487$.
Specht, D.F. 1991. A General Regression Neural Network. IEEE Transactions Neural Networks 2, 568 - 576.

Shafiee, S. dan Topal, E. 2010. An Overview of Global Gold Market and Gold Price Forecasting. Jurnal Resources Policy vol. $35,178-189$.

Sopipan, N., Sattayatham, P., dan Premanode, B. 2012. Forecasting Volatility of Gold Price using Markov Regime Switching and Trading Strategy. Journal of Mathematic Finance 2, $121-131$.

Theodosiou, M. 2011. Disaggregation \& Aggregation of Time Series Components : a Hybrid Forecasting Approach using Generalized Neural Networks and the Theta Method. Neurocomputing vol. 74, 896 905.

Wang, Y.S. dan Chueh, Y.L. 2012. Dynamic Transmission Effects between the Interest Rate, the US dollar, and Gold and Oil Prices. Jurnal Economic Modelling 30, 792 $-798$.

Witjaksono, A.A. 2010. Analisis Pengaruh Tingkat Suku Bunga SBI, Harga Minyak Dunia, Harga Emas Dunia, Kurs Rupiah, Indeks Nikkei 225, dan Ondeks Dow Jones terhadap IHSG. Laporan tesis.

Zou, H.F., Xia, G.P., Yang, F.T., Wang, H.Y. 2007. An Investigation and Comparison of Artificial Neural Network and Time Series Model for Chinese Food Grain Price Forecasting. Neurocomputing vol. 70, 2913-2923. 